\title{
Dogs in the Duck Factory
}

By J. BERNARD GOLLOP, Saskatoon

Reprinted from C. I. L. Oval, Vol. 25. No. 5, October, 1956

Hunters who are enjoying this year's near-record crop of waterfowl may tender part of their thanks to some prairie-bred dogs who have played an important part in the joint Canadian-United States waterfowl management program . . . This year (1956), retrievers and spaniels were used in the banding programs of the Canadian Wildlife Service, co-operating with the U.S. Fish and Wildlife Service, provincial game branches, Ducks Unlimited, and the Wildlife Management Institute. Most of the dogs were used in special study areas spotted across the southern parts of the Prairie Provinces in the area which has become known to conservation people as the "duck factory."

Kindersley, Saskatchewan, is the site of one of these study areas. Here biologists of the Canadian Wildlife Service have been using dogs for the past four years. This year their partners were Rusty, a four-yearold Labrador-golden retriever cross; Widgeon, a Ch€ sapeake Bay retriever, and Chips, a Labrador retriever pup.

The importance of the part the dogs play can best be understood by looking at the purposes of the special study areas. The first objective is for ground crews to determine, by census, the size of the breeding populations in May and June and the number of young produced in July and August .... It is necessary to find out approximately what proportion of the ducks actually on the ground is recorded by the aircrews who conduct continent-wide surveys to determine waterfowl population trends and upon whose data hunting regulations for each year are largely based .. The comparisons between the two figures assume, of course that the ground crews are getting accurate counts of the birds present. Without dogs, the men have always found it difficult enough to feel they were making a complete count even when they are "working" pairs of breeding ducks. With broods, the problem is greater because of the first sign of any disturbance mallard and pintail hens are liable to leave the water and head across country with their broods. If the dogs were not used to find and retrieve at least some of the members of these broods, they would go unrecorded.

The second objective of the ground study areas is to keep in close contact with ducks through the season, and to work on specific phases of the life history of one or several species. Dogs are a valuable asset, finding nests both by accidentally flushing the hens and by scenting them. Last spring at Kindersley, Widgeon found four mallard hens on their nests, thereby saving the crew the trouble of setting traps to catch and band them. The birds were first located by scent at distances up to 10 yards, and then either caught in the brush or picked out of the air.

It is in the banding of broods however, both on the study areas and by roving crews, that dogs really come into their own. Since 1954, al the organizations banding in Canade have directed their efforts towarc getting adequate samples of flightles: young mallards. This species is thi most abundant North American ducl as well as the biggest contributor ti the hunter's bag. In Canada, it i also the species causing most of th damage to the western farmer' swathed wheat and barley crops. Bu the type of banding done in the pas voluminous as it has been, ha yielded little information about th relative importance of the route taken and the wintering areas use by mallard populations from specifi portions of the breeding ground More of this information, as well a data on variations in shooting pres sure from year to year, is still neede to bridge the gap between waterfor surveys and hunting regulations.

At Kindersley, more than 3,0r flightless young mallards have bee banded in the past four years $k$ Canadian Wildlife Service crev using dogs like Rusty, Widgeon ar Chips. Another 2,000 have bef caught by herding or driving broo into traps. The dogs were used on on small sloughs containing few than half a dozen mallard brooc traps were used for larger numbe on areas large enough so that $t$ : mallards would condescend to rema while a trap was set up.

Most of this banding was do 
In a block of agricultural land some 0 miles square, and it was accompshed by. one crew in 1953, two in 954 and 1955, and three in 1956. he crews have consisted of one or wo men and a dog, although one lan has sometimes handled two dogs. he daily catch has ranged from two 75 mallards per crew and has veraged 29 .

To get a well-distributed sample young mallards, just about every ough in the area has to be worked -whether or not the birds are seen it. In many cases a mallard brood afing on the shore will turn around nd walk into the grass as soon as a ehicle stops or a banding crew ppears; such a brood is seldom oted until the dog starts retrieving dividuals from it. On sloughs with emergent vegetation, mallard roods on the water will usually head r shore if they feel that they can cape unnoted. If not they may ead for the deepest water, where ley have to be carefully herded shore either by wading or by canoe fore the dog can work effectively.

When on land the dog works the ear-shore cover on the first trip cound the slough, and then the area $p$ to 300 yards back from shore on he second coverage. As a dog aproaches a duck, his tailwagging beeds up until he is at close range; ien he suddenly comes to an abrupt alt, tensely waiting a few seconds or his eyes to see or his ears to hear hat his nose tells him is there. $\mathrm{He}$ en pounces in the general area, cates the duck, works it out of ver and carries it to the nearest ander.

It might seem that when working ith these "upland waterfowl" the field men should be able to do their own duck catching, but this is not possible. One reason is that the birds usually rush into the thickest-cover bushes, grass or standing crops. Ancther reason is that they seldom stop near the water's edge, and within a matter of minutes may be scattered within a one-mile radius of the shore . . And if the crew needs another excuse, they can only admit that they just don't have the nose for the job. The field books show that while each member of the two-man crew was finding one mallard, the the dog had found and caught eleven. When dogs learn to attach bands and keep the records, biologists will be out of the mallard-banding business.

While dogs work best on land, they are also efficient in shallow water. After a duck has dived three or four times, the dog is usually in a position where he can put his head under water and come up with the bird. In water deep enough so that the dog has to swim, he can still scent birds in dense aquatic vegetation, but here it is usually the handler rather than the dog who does the actual catching.

Training dogs for this work differs little from that required for field trails ... Any retriever with a good nose basic obedience training and at least a rough idea of hand signals should develop into a good duck banding dog if he has what a dog handler calls a "soft mouth" and if he is otherwise gentle with live birds.

As this season progresses down the flyways, hunting dogs from many of the 26 states visited by Kindersleyraised mallards will be retrieving banded birds that have once before been handled by one of three other dogs-Rusty, Widgeon or Chips.

\title{
1957 Summer Banding
}

\author{
by DR. STUART HOUSTON
}

My summer banding excursion sulted in a total of 1845 birds being inded, (about a thousand less than st year). These included 876 Ringlled Gulls, 342 White Pelicans, 110 ommon Terns, 75 Double-crested ormorants, 73 California Gulls, and Franklin's Gulls. The latter were anded at Beaufield Marsh, south of errobert on June 25 th, and the next day Frank Switzer and I took part in a drive of moulting ducks with Bernie Gollop's Canadian Wildlife Service crew aided by Tom Sterling's Ducks Unlimited air boat. A by-product of this drive was 24 adult and 34 immature Eared Grebes. Five moulting male Ring-necked Ducks were also banded.

Little Quill Lake showed a sur- 